\section{A note on the first registered Mollusca in the National Zoological Collections at the Zoological Survey of India}

\author{
Basudev Tripathy ${ }^{1} \&$ R. Venkitesan ${ }^{2}$ \\ ${ }^{1 \& 2}$ Malacology Division, Zoological Survey of India, Prani Vig- \\ yan Bhawan, 535, M-Block, New Alipore, Kolkata, West Bengal \\ 700 053, India \\ Email: ${ }^{1}$ tripathyb@yahoo.co.uk (corresponding author), \\ 22drvencat@rediffmail.com
}

Natural history museums have long been recognized as centres for systematic and biological research. Museum collections are also important reference systems for the study of the diversity of living organisms. The voucher specimens collected during various faunistic field surveys and explorations, preserved and deposited in natural history museums help in recognizing multiple species in a complex of closely related species, variation in traits of populations that affect morphology, ecology, behaviour or physiology, errors or omissions in keys or guides used for identification. The Zoological Survey of India (ZSI), since its inception, has in its custody and care, collections of the Natural History Museum, Calcutta (Kolkata) that are over 200 years old, as well as subsequent collections made by scientists and staff of ZSI since 1916. As per Section 39 of the Biological Diversity Act, 2002, ZSI

Date of publication (online): 26 November 2011

Date of publication (print): 26 November 2011

ISSN 0974-7907 (online) | 0974-7893 (print)

Editor: Tan Koh Siang

Manuscript details:

Ms \# 02836

Received 14 June 2011

Final received 24 August 2011

Finally accepted 03 October 2011

Citation: Tripathy, B. \& R. Venkitesan (2011). A note on the first registered Mollusca in the National Zoological Collections at the Zoological Survey of India. Journal of Threatened Taxa 3(11): 2217-2220.

Copyright: @ Basudev Tripathy \& R. Venkitesan 2011. Creative Commons Attribution 3.0 Unported License. JoTT allows unrestricted use of this article in any medium for non-profit purposes, reproduction and distribution by providing adequate credit to the authors and the source of publication.

Acknowledgements: We are thankful to the Director, Zoological Survey of India, Kolkata for access to the Murex materials of the NZC, Kolkata and also going through the earlier draft of the manuscript. We are also grateful to the anonymous reviewers for their comments and suggestion for improving the contents of the manuscript.

OPEN ACCESS | FREE DOWNLOAD is notified as Designated National Repository for Zoological Collections (NZC) of India. The NZC

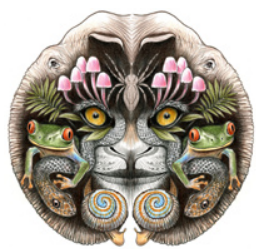
housed at ZSI now contains more than 30,00,000 authentically identified specimens comprising over 90,000 known species of animals (Ramakrishna \& Alfred 2007). The NZC present in different sections of ZSI was acquired from the $\mathrm{Mu}$ seum of the Asiatic Society of Bengal, the Zoological section of the Indian Museum, and collections through various surveys till now which started in the early part of $19^{\text {th }}$ century.

Many distinguished naturalists such as John McClelland, Edward Blyth, W. Blanford, H. Blanford, T. Cantor, Francis Day, H.H. Godwin Austen, T. Hardwicke, B. Hodgson, G. Nevill, H. Nevill, F. Stoliczka, W.M. Sykes, W. Theobald, S.R. Tickell, J. Anderson and $\mathrm{H}$. Wood-Mason significantly contributed in documenting the fauna of the Indian subcontinent in the early years of the 19th and 20th centuries. Numerous specimens were also presented to the Indian Museum by friends of the department such as officers of the Geological and Botanical Surveys of India, Indian Forest Services and the Indian Medical Services, by planters in various parts of India, and finally by the officers of the Hoogly Pilot Service. However, serious zoological investigations were first undertaken in India in the last quarter of the $19^{\text {th }}$ century. During the tenure of John Anderson (First Superintendent of the Indian Museum, 1865-1886), there were a series of marine expeditions carried out by the Indian Museum (Anonymous 1914). The Investigator-I (1881-1905) and Investigator-II (1908-11 \& 1921-1926) expeditions dredged several interesting mollusks and of them some collections were studied by E.A. Smith (1906). Several scientific teams from the ZSI also surveyed the molluscs of India from both the terrestrial and aquatic environments. However, the history of first molluscan collections in ZSI dates back to 1872 . Dr. J. WoodMason, an officer of the Indian Museum collected the first molluscan specimens from the Andaman Islands (Rao \& Dey 2000). Perhaps this was due to the series

Abbreviations: BMNH - British Museum (Natural History), London; USNM - National Museum of Natural History, Washington, D.C., U.S.A.; DMNH - Delaware Museum, Greenville, U.S.A.; NZC-ZSI - National Zoological Collections at Zoological Survey of India 
of expeditions carried out during 1865-1886. However, registering the collections started later. The records present in the Indian Museum show that Murex trapa, also commonly known as Rare-spined Murex, is the first registered specimen of the then Indian Museum, which was collected by J. Barnett, Esq. Branch Pilot, P.V. Cassandra on 22 August 1884. It is now presently in the NZC. This is an excellent example of the contributions of private donors to the zoological collections in the Indian Museum. The record indicates that it was collected from Sandhead, Bay of Bengal and it could be possible that J. Barnett, a Hugli Pilot, donated these specimens to the museum (The Indian Museum: 1814-1914). The details regarding the Rare-spined Murex are provided below.

\section{Classification of Murex trapa}

Phylum : Mollusca

Class : Gastropoda

Order : Neogastropoda

Family : Muricidae

Genus : Murex

Species : trapa

\section{Murex trapa Roeding, 1798}

1777. Purpura hystrix Martini Neues syst. Conch. Cab. Geo. und besch. VoI. 3, vi +434 pp., pIs lxvicxxi.

1798. Murex trapa Roeding Mus. Bolten., p. 145. (Type locality: Tranquebar, India)

1822. Murex rarispina Lamarck Hist. nat. Anim. Sans. Vert., 7: 158.

1845. Murex martinianus Reeve Conch. Icon., 3 Murex. sp. 72, pl.18, fig. 72.

1940. Murex trapa: Crichton, Journal of Bombay Natural History Society., 42: 331, pl.3, fig.5.

1942. Murex tribulus var. trapa Gravely, Bull. Madras Govt. Mus. New Ser. (Nat. Hist), 5(2): 49.

1952. Murex trapa: Satyamurti, Bull. Madras Govt. Mus. New Ser. (Nat. Hist), 1(2): 153, pl.14, fig. 4.

1961. Murex trapa: Menon, Datta Gupta \& Das Gupta, Journal of Bombay Natural History Society, 58(2): 486, pl.7, fig.57.

1967. Murex trapa Cernohosky, Marine Shells of the Pacific, 1: 117, pl. 23, fig. 138.

1976. Murex trapa Radwin \& D'Attilio, Murex shells of the World: 72, pl.10.fig.14.

1986. Murex trapa: Tikader, Daniel \& Subba Rao,
Sea shore animals of Andaman and Nicobar Islands, Zoological Survey of India, p.170.

1988. Murex trapa: Ponder \& Vokes, Rec. Aust. Mus. Suppl. 8: 41. figs. 17-19, 67 G,H;71 B,C; 73D; $83 \mathrm{G}, \mathrm{H}$.

1990. Murex trapa: Pinn, Sea Shells of Pondicherry, Nehru Science Centre, p. 68, fig. 117.

1991. Murex trapa: Rao, Rao \& Maitra, Fauna of Orissa, State Fauna series, 1(3): 62; Zoological Survey of India.

1993. Murex trapa: Subba Rao \& Surya Rao, Rec. Zoological Survey of India Occ. Paper No., 153: 42, pl. 5, figs. 9-11, Text fig. 17.

2000. Murex trapa: Subba Rao \& Dey, Rec. zool. Surv. India Occ. Paper No., 187: 102.

2001. Murex trapa: Mahapatra, Fauna of Godavari Estuary, Estuarine Ecosystem series, 4: 66. Zoological Survey of India .

2003. Murex trapa: Subba Rao, Rec. Zoological Survey of India Occ. Paper No., 192: 229, pl. 54, figs.1-2.

2007. Murex trapa: Ramkrishna, Dey, Barua \& Mukhopadhya, Fauna of Andhra Pradesh, State Fauna series, 5(7): 85. Zoological Survey of India.

2008. Murex trapa: Mahapatra, Fauna of Krishna

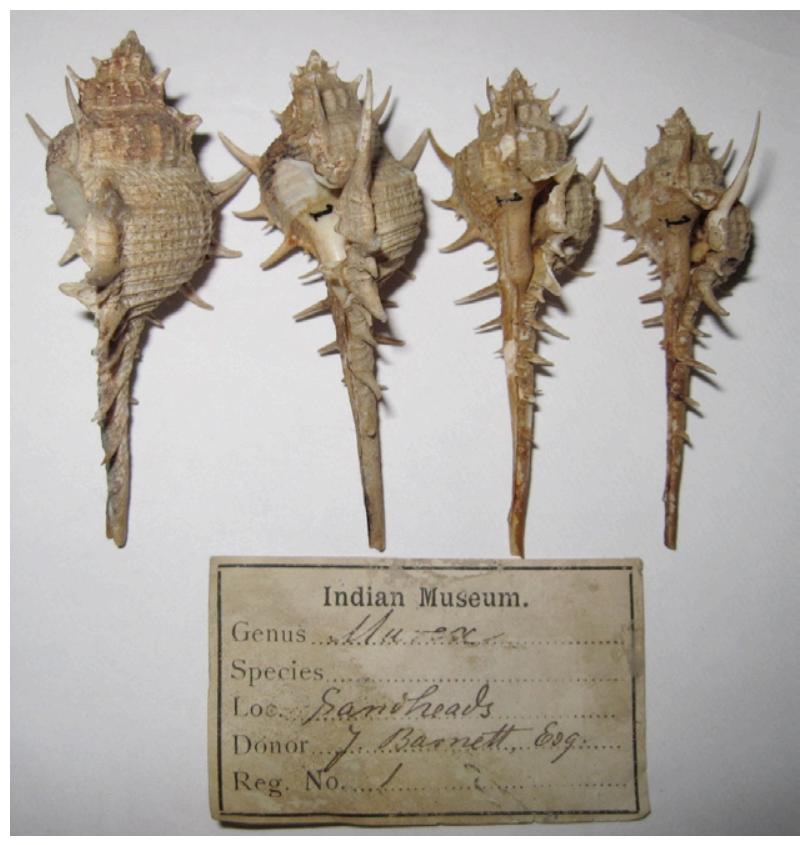

Image 1. Murex trapa Roeding. Collected by J. Barnett, Esq. from Sandhead, Bay of Bengal on 22.viii.1884 (4 exs.) [Indian Museum (NZC at ZSI), 1884, 001] 
Estuary, Estuarine Ecosystem series, 5: 130. Zoological Survey of India.

Material present in the NZC of ZSI, Kolkata: 22.viii.1884, 4 exs. Sandheads, Bay of Bengal; coll. J. Barnett Esq., (Registration No. 001) (Image 1).

Records \& distribution: India: Madras (BMNH), Tuticorin (USNM; DMNH), Andaman Islands (DMNH), West Bengal, Orissa, Andhra Pradesh, Tamil Nadu (NZC-ZSI); China, Fiji, Indonesia, Madagascar, Malaysia to Japan, Mauritius, Myanmar, Philippines and Thailand (Ponder \& Vokes 1988).

Type locality: Tranquebar, Tamil Nadu, India

Remarks: In re-describing Murex trapa, Ponder \& Vokes (1988) selected figure No. 1056 from two of Martini's figures (see Martini 1777) cited by Roeding (1798) as the type material (see Image 2). Martini (1777: 358) gives Tranquebar, Tamil Nadu, India as the type locality and indicates that it is very common at that locality. Reeve (1845) while describing Murex trapa recognized that Martini's Plate No. 72 (Conchylien Cabinet) illustrated Murex martinianus (Martini's Murex) but presumably was unaware of Roeding's earlier name for that (Roeding 1798).

The shell of this species is readily distinguished by its tall spire, angulated whorls and short spines. It is very abundant in shallow waters. The relationship of this species may be with the M. scolopax species group, because it resembles most shell characters except for having a 'closed', not 'open', outer lip. It is included in the M. tribulus species group by some authors. According to Rao \& Rao (1993), this species closely agrees with $M$. tribulus but differs in having an elevated and acute spire, and sub-angulate whorl; canal bearing a few spines on the upper part, and having a more prominent labial tooth. This species was also reported from the Gulf of Kachchh by Menon et al. (1961) but the figure given by them suggests it to be M. tribulus. So far there is no record of this species from anywhere along the west coast of India or along the Arabian coast, although there are records from Madagascar and Mauritius (Ponder \& Vokes 1988).

Importance of designated national repository: The Zoological Survey of India (ZSI) is a century-old organization (established in 1916) that mainly deals with the exploration, survey, inventorying and monitoring of faunal diversity in various states, ecosystems and protected areas of India (http://zsi.gov.in). It is the only organization in the country involved in the taxo-

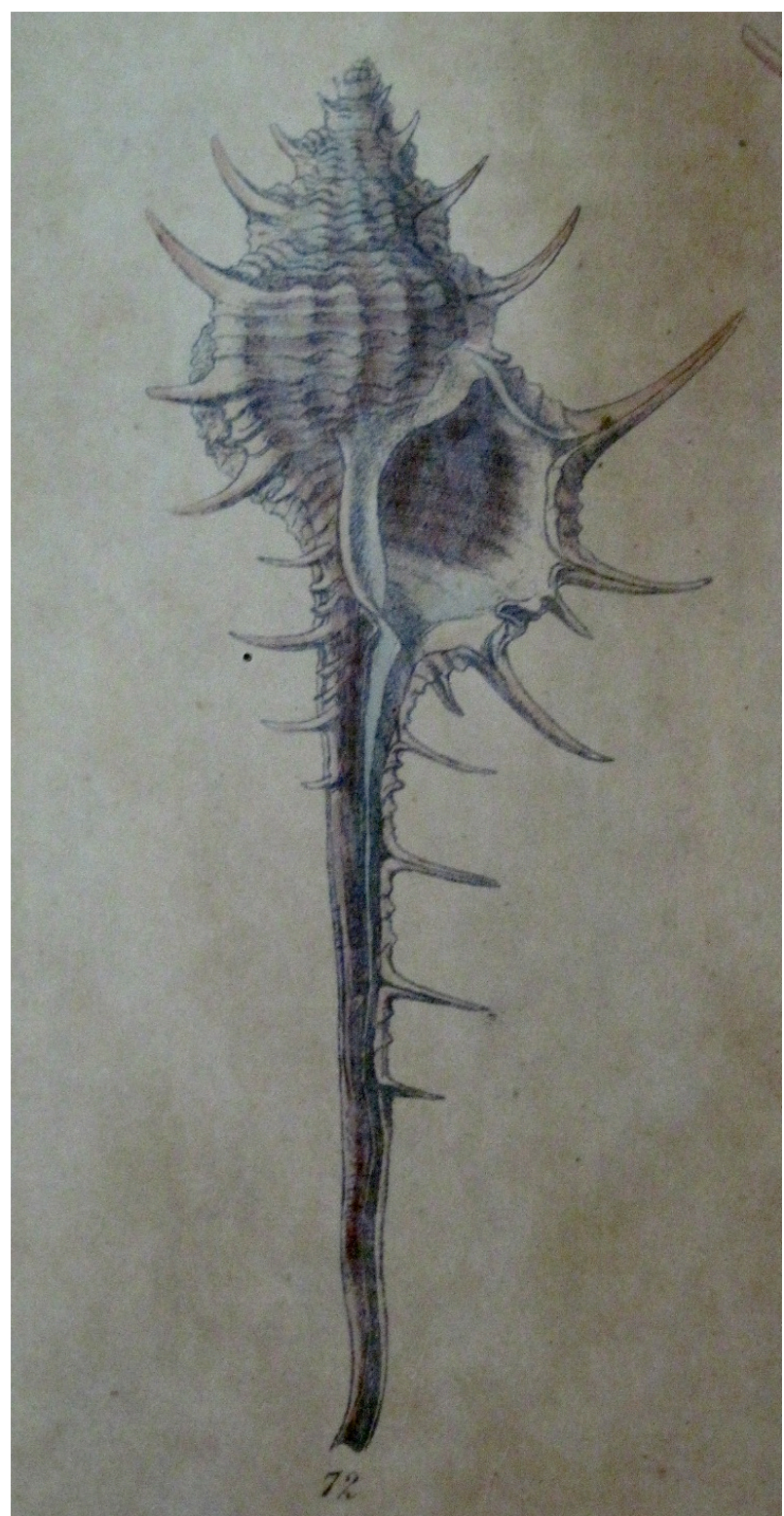

Image 2. Original Sketch of Murex martinianus [Adopted from Conch. Cab.Vol. III, PI. XVIII Fig. 72]

nomic study of all kinds of animals, from Protozoa to Mammalia, occurring in all possible habitats. ZSI is also the designated national repository for animal collection and is a storehouse of zoological collections. It serves as a fundamental resource for the identification of zoological specimens by way of comparison with known taxa, as well as through morphological and molecular studies to compare the lineage of taxa. 


\section{REFERENCES}

Anonymous (1914). The Indian Museum, 1814-1914. Calcutta, Pub. by the trustees of the Indian museum and printed at the Baptist Mission Press, xi p., 1 1., 136, 1xxxvii p.

Martini, F.H.W. (1777). Neues sytematisches ConchylienCabinet, fortgesetzt durch Johann Heironymus Chemnitz. Nrnberg: G. N. Raspe. Vol.3 pp. vi + 1-434, Pls. 66-121.

Menon, P.K.B., A.K. Duttagupta \& D. Dasgupta (1961). The marine fauna of the Gulf of Kachchh. II. Gastropoda. Journal of the Bombay Natural History Society 58(2): 475 494.

Ponder, W.F. \& E.H. Vokes (1988). A revision of the IndoWest Pacific fossil and recent species of Murex s.s. and Haustellum (Mollusca: Gastropoda: Muricidae). Records of the Australian Museum 8(Supplement) : 1-160
Ramakrishna \& J.R.B. Alfred (2007). Faunal Resources of India. Published by Director, Zoological Survey of India, Kolkata, 1-427pp.

Roeding, P.F. (1798). Museum Boltenianum sive Catalogus cimeliorum e tribus regnis naturae quae olim collegerat Joa. Fried Bolten, M.D. P.D. Hamburg, viii+199pp.

Rao, N.V.S. \& A. Dey (2000). Catalogue of marine molluscs of Andaman and Nicobar Islands. Records of the Zoological Survey of India, Occasional paper No 187: 1-323.

Rao, N.V.S. \& K.V.S. Rao (1993). Contribution to the knowledge of Indian marine mollusca Pt. 3. Family : Muricidae. Records of Zoological Survey of India, Occasional Paper, No. 153: 1-233.

Smith, E.A. (1906). Natural History Notes from RIMS Investigator Series III. No. 10. on Mollusca from the Bay of Bengal and the Arabian Sea. The Annals and Magazine of Natural History 7(18): 157-175 \& 245-263. 